FINANCIAL: Jurnal Akuntansi

Published by Program Studi Akuntansi STIE Sultan Agung

Volume 6-Nomor 1, Juni 2020, (HIm 59-69)

ISSN-P: 2502-4574, ISSN-E: 2686-2581

Available online at: https://financial.ac.id/index.php/financial

\title{
PENGARUH KONDISI KEAMANAN DALAM NEGERI TERHADAP HARGA SAHAM PADA PERUSAHAAN LQ45
}

\author{
Maulida Kautsarina ${ }^{1)}$, Izza Alfiatur Rohmaniah ${ }^{2)}$, Kharis Fadlullah Hana ${ }^{3)}$ \\ ${ }^{1,2,3}$ IAIN Kudus, Jawa Tengah, Indonesia. \\ Email: ${ }^{1}$ Maulidakautsarina@gmail.com, ${ }^{2}$ izzaalfi14@gmail.com, ${ }^{3}$ Kharis@ @iainkudus.ac.id
}

\begin{abstract}
Abstrak
Penelitian ini bertujuan untuk mengetahui perubahan harga saham sebelum dan sesudah peristiwa pengeboman yang terjadi pada tahun 2016-2019 dengan melihat reaksi pasar modal Indonesia terhadap kondisi keamanan dalam negeri pada peristiwa pengeboman tersebut. Populasi pada penelitian ini yaitu seluruh harga saham pada perusahaan yang tergabung dalam indeks LQ45 yang benar-benar aktif diperdagangkan di Bursa Efek Indonesia (BEI) yang terdiri dari 45 sampel. Teknik analisis yang digunakan dalam penelitian ini adalah mengamati, mendeskripsikan dan menganalisis data harga saham perusahaan yang tergabung dalam perusahaan LQ45 pada tahun 2016-2019 di web resmi pasar modal Indonesia http://www.idx.co.id. Hasil penelitian menunjukkan bahwa pasar modal khususnya perusahaan yang tergabung dalam indeks LQ45 merespon negatif peristiwa pengeboman yang terjadi di Indonesia, hal ini dapat dibuktikan dengan melihat grafik harga saham LQ45 selama peristiwa pengeboman. Tetapi, H+1 setelah peristiwa bom Sibolga terjadi perusahaan LQ45 mampu bangkit kembali dengan kenaikan harga saham yang cukup signifika sehingga menyebabkan harga saham perusahaan tersebut kembali stabil.
\end{abstract}

Kata Kunci : Studi Peristiwa, Peristiwa Pengeboman, Pasar Modal, Harga Saham

\section{THE EFFECT OF STATE SECURITY CONDITIONS ON STOCK PRICES LISTED ON LQ45 COMPANY}

\begin{abstract}
This research aims to determine the change in the price of the stock before and after the bombing event that occurred in 2016-2019 by looking at the reaction of Indonesian capital market to the domestic security conditions at the event of the bombing. The population in this research is the entire share price of companies incorporated in the LQ45 index which is actually actively traded on the Indonesia Stock Exchange (IDX) consisting of 45 samples. The analytical techniques used in this study are observing, describing and analyzing the stock price data of the company incorporated in the LQ45 company in 2016-2019 on the official website of the Indonesian capital market http://www.idx.co.id. The results showed that the capital market in particular the company incorporated in the index of LQ45 responds negatively to the event of bombing occurring in Indonesia, this can be proved by looking at the stock price chart of LQ45 during the bombing event. However, $H+1$ After the bombing incident occurred LQ45 company was able to bounce back with a significant share price increase that caused the company's share price to return stable.

Keywords: Event Study, Bombing Events, Capital Markets, Stock Prices.
\end{abstract}

Article History: $\quad$ Received: 15 Mei 2020 Revised: 16 Mei 2020 Accepted: 02 Jun 2020 


\section{PENDAHULUAN}

Pada dasarnya, hampir di setiap negara memiliki pasar modal. Adapun tujuan adanya pasar modal di suatu negara yaitu untuk menciptakan fasilitas bagi keperluan industri serta fasilitas dalam memenuhi permintaan dan penawaran modal. Peran pasar modal yaitu sebagai sarana untuk meningkatkan kebutuhan dana jangka panjang dengan cara menjual saham atau menerbitkan obligasi (Jusman, 2019) Pasar Modal yang berkembang di negara sedang berkembang atau di negara industri baru tidak terlepas dari pengaruh faktor ekonomi dan faktor non-ekonomi. Adapun salah satu faktor non-ekonomi yang dapat mempengaruhi perkembangan pasar modal yaitu kondisi keamanan suatu Negara. Aksi terorisme atau pengeboman merupakan salah satu faktor yang dapat mempengaruhi kondisi keamanan suatu Negara. (Kristiyanto \& Hermuningsih, 2018). Dalam suatu negara peristiwa terorisme merupakan tindakan kekerasan yang dilakukan oleh oknum tertentu untuk menimbulkan rasa ketakutan masyarakat agar oknum tersebut mampu mencapai tujuannya (Romadhona, 2019).

Dalam beberapa tahun terakhir, aksi terorisme telah terjadi di Indonesia dengan motif yang berbeda-beda seperti peledakan bom yang sempat mencemaskan masyarakat Indonesia. Teror bom mungkin tidak berpengaruh besar terhadap ekonomi suatu negara. Namun jika peristiwa tersebut tidak diantisipasi secara serius, tidak menutup kemungkinan geliat ekonomi juga akan terganggu. Selain itu, aksi tersebut juga mengganggu stabilitas politik dan iklim investasi. Bagi para investor, aksi terorisme yang terjadi di suatu negara dianggap sebagai sinyal bahwa negara tersebut tidak nyaman dan tidak baik-baik saja (Romadhona, 2019). Sebagai contoh, adanya gangguan keamanan di dalam negeri akibat peristiwa yang akhir-akhir ini sering terjadi yakni peristiwa pengeboman dapat mengganggu stabilitas politik dan iklim investasi yang akan mempengaruhi keputusan investor (Tecualu \& Megge, 2010). Sebuah peristiwa akan memiliki kandungan informasi apabila peristiwa tersebut dapat mempengaruhi harga saham sehingga para investor akan berpikir ulang atas keputusannya dalam berinvestasi. Besarnya pengaruh suatu peristiwa terhadap kondisi pasar modal dapat dilihat melalui perubahan harga saham (Cindy \& Soewarno, 2018).

$\begin{array}{ccc}\text { Januar } & \text { Romadhona dalam } \\ \text { penelitiannya menyimpulkan } & \text { bahwa }\end{array}$ ditinjau dari harga saham menunjukkan bahwa tidak ada perbedaan yang signifikan mengenai average abnormal return pada saham-saham LQ 45 sebelum dan sesudah peristiwa bom bunuh diri 13 Mei 2018 di Surabaya (Romadhona, 2019). Penelitian yang sama namun dengan tempat yang berbeda juga dilakukan oleh Setya Kristiyanto dan Sri Hermuningsih, dalam penelitian tersebut disimpulkan bahwa ada perbedaan secara signifikan antara rata-rata Return sebelum dan sesudah peristiwa Ledakan Bom Thamrin LQ45 di Bursa Efek Indonesia (Kristiyanto \& Hermuningsih, 2018).

Dengan demikian, penelitian ini bertujuan untuk mengembangkan penelitian terdahulu karena di penilitian terdahulu hanya memfokuskan pada satu tempat. Sedangkan pada penelitian ini membahas lebih menyeluruh dari beberapa peristiwa pengeboman yang terjadi di Indonesia. Selain itu penelitian ini juga bertujuan untuk membuktikan penelitian 
terdahulu mengenai pengaruh peristiwa pengeboman di Indonesia pada tahun 2016-2019 terhadap harga saham. Peristiwa pengeboman yang akan diteliti dalam penelitian ini adalah peristiwa Bom Thamrin yang terjadi pada 14 Januari 2016, peristiwa Bom Kampung Melayu pada 24 Mei 2017, peristiwa bom Surabaya pada 13 Mei 2018, dan peristiwa pengeboman Sibolga pada 12-13 Maret 2019.

\section{LANDASAN TEORI}

Menurut Samsul, ada banyak peristiwa yang dapat mempengaruhi harga saham di pasar ketika peristiwa tersebut terjadi. Setiap peristiwa memiliki karakteristik yang berbeda-beda yakni ada peristiwa yang berpengaruh lamban terhadap harga saham dan ada juga peristiwa yang berdampak seketika dan drastis. Peristiwa isidentiil yang tidak terulang kembali setiap tahun tetapi dapat terjadi sewaktu-waktu, seperti ledakan bom dapat berdampak seketika dan drastis terhadap harga saham. Peristiwa terorisme (pengeboman) kerap menjadi bumerang utama pemicu fluktuasi harga saham di bursa efek karena peristiwa pengeboman tersebut akan menimbulkan kepanikan pada para investor dan menyebabkan kurangnya kepercayaan dari para investor tersebut sehingga mereka beramai-ramai ingin menjual sahamnya atau mungkin memindahkan investasinya ke pasar uang. Selain itu peristiwa teror menjadi issue negatif yang dapat mengancam stabilitas negara dan menimbulkan gejolak di pasar modal. Oleh sebab itu, perlu adanya studi peristiwa (event study) untuk mempelajari pengaruh suatu peristiwa terhadap bursa saham (Sari et al., 2017: 3).
Efficient Market Hypotesis menjelaskan bahwa respon suatu informasi terhadap harga saham, yaitu sebagaimana suatu informasi dapat mempengaruhi harga saham. Dalam hipotesa pasar efisien, suatu pasar akan merespon dengan cepat adanya sebuah informasi (Cindy dan Soewarno, 2018: 23). Informasi mempunyai peranan penting terhadap pasar modal, dalam hal ini mengingat bahwa harga merupakan refleksi semua informasi yang relevan (Eficient Market Hypotesis). Informasi publik digunakan oleh para investor dalam mengambil keputusan untuk berinvestasi, antara lain informasi yang berkaitan dengan kondisi fundamental perusahaan seperti laporan keuangan serta pengumuman tindakan korporasi dan faktor makroekonomi seperti tingkat suku bunga, tingkat pertumbuhan industri, dan tingkat inflasi. Namun, tidak dapat dipungkiri pula bahwa peristiwa non makroekonomi juga akan berpengaruh terhadap pasar modal (Utama and Hapsari, 2012: 100-101).

\section{Event Study}

Studi peristiwa (event study) yaitu studi yang mempelajari tentang reaksi pasar terhadap suatu peristiwa (event) dimana informasinya telah dipublikasikan sebagai suatu peristiwa. Terdapat beberapa tujuan mengapa studi peristiwa banyak digunakan, yaitu untuk menganalisis pengaruh dari adanya suatu peristiwa terhadap nilai perusahaan, untuk mengukur langsung pengaruh peristiwa terhadap harga saham perusahaan dengan terjadinya suatu peristiwa karena harga saham tersedia pada saat peristiwanya terjadi, dan kemudahan dalam mendapatkan datanya. Apabila sebuah pengumuman mengandung informasi (information content), maka diharapkan akan terjadi reaksi oleh pasar 
ketika pengumuman tersebut diterima oleh pasar. Reaksi pasar sendiri ditandai dengan terjadinya perubahan harga sekuritas yang bersangkutan (Jusman, 2019: 202). Mackinlay menyebutkan bahwa dalam melakukan Event Study ada langkahlangkah yang harus diperhatikan diantaranya :

1. Mendefinisikan kejadian yang diminati, yakni berupa informasi yang tersedia di pasar.

2. Membangun teori yang mampu memberikan alasan atau mampu menjelaskan respon keuangan terhadap kejadian tersebut.

3. Mengidentifikasi tanggal kejadian (event date).

4. Memilih Event Windows yang sesuai dengan justifikasi jaraknya.

5. Menyesuaikan perusahaan mana yang mengalami kejadian tersebut.

6. Menghitung Abnormal Return selama Event Windows, dan menguji tingkat signifikansinya (Octavera and Rahadi, 2019: 61).

\section{Pasar Modal}

Suatu pasar akan dikatakan efisien ketika pasar tersebut mampu bereaksi secara cepat dan akurat untuk menuju harga keseimbangan baru yang sepenuhnya telah mencerminkan informasi yang tersedia (Jogiyanto, 2013: 547). Pasar modal secara umum adalah sarana atau tempat bertemunya orang-orang atau pihak yang mempunyai kelebihan dana (surplus fund) dengan orang-orang atau pihak dengan dana terbatas (defisit fund), di mana tujuan bertemunya mereka yaitu untuk berdagang sekuritas (Manan, 2017: 23). Pasar modal di suatu negara dapat digunakan sebagai ukuran dalam melihat maju mundurnya dinamika bisnis yang terjadi di negara tersebut (Romadhona,
2019: 3). Adapun peran penting adanya pasar modal untuk perekonomian saat ini adalah selain menjadi fasilitas untuk investor dalam mengalihkan dananya, pasar modal juga dapat memberikan sejumlah return atas karakteristik resiko investasi yang dimiliki kepada para investor pasar modal (Arde and Kesuma, 2017: 3081).

\section{Terorisme}

Terorisme dapat diartikan sebagai suatu ancaman atau tindakan kekerasan yang dilakukan oleh oknum tertentu dan ditujukan kepada sasaran yang tidak ada hubungan langsung dengan pelaku, di mana aksi tersebut dapat menimbulkan kerusakan, kematian, ketakutan, ketidakpastian dan keputusan massal. Tindakan ini dilakukan dengan motif memaksakan kehendak kepada pihak yang dianggap lawan oleh para oknum (kelompok teroris) agar kepentinngankepentingan mereka diakui dan dihargai (Mustofa, 2002: 31). Selain menimbulkan kerusakan, kematian, dan lain-lain, aksi terorisme khususnya pengeboman juga berakibat pada kinerja IHSG dan kinerja keuangan. Dampak lain yang timbul dengan adanya pengeboman (terorisme) yaitu adanya penurunan kinerja di perekonomian terutama di performa IHSG dan pelemahan nilai tukar rupiah terhadap mata uang asing (Widajatun dan Ichsani, 2019: 66).

\section{Saham}

Saham merupakan salah satu instrument pasar modal yang sangat diminati oleh investor karena sifatnya lebih mudah memberikan tingkat keuntungan yang menarik bagi para investor. Fahmi mengemukakan bahwa dengan adanya investasi dapat menciptakan laba maksimum atau laba yang diharapkan 
(laba aktual) dan penciptaan kekayaan bagi pemegang saham serta kontribusi untuk pembangunan bangsa (Romadhona, 2019: 3). Terdapat dua jenis saham perusahaan berdasarkan kemampuan dalam hak tagih yaitu, Pertama saham preferen (Preferred Stock) merupakan saham yang memiliki karakteristik gabungan antara obligasi dan saham biasa, karena bisa menghasilkan penghasilan tetap. Kedua, saham biasa (Common Stock) mewakili klaim kepemilikan pada penghasilan dan aktiva yang dimiliki perusahaan dimana pemegang saham biasa memiliki kewajiban yang terbatas (Supramono, 2014: 6). Sedangkan harga saham adalah sejumlah uang yang di keluarkan untuk memperoleh bukti kepemilikan suatu perusahaan. Adapun faktor-faktor yang mempengaruhi harga saham, yakni kondisi fundamental emiten, hukum permintaan serta penawaran, tingkat suku bunga, valuta asing, dana asing di bursa, news dan rumors, dan indeks harga saham (Verawaty and Pratiwi, 2016: 3).

\section{Indeks LQ45}

Indeks LQ45 merupakan indeks yang terdiri dari 45 saham (ekuitas) yang sering diperdagangkan dan memiliki kapitalisasi pasar yang sangat besar. Setiap enam bulan tercatat saham baru yang masuk ke dalam indeks LQ45 (Karmila, 2010: 48)

\section{METODE PENELITIAN}

Penelitian ini merupakan event study (studi peristiwa). Definisi dari studi peristiwa adalah studi yang mempelajari reaksi pasar modal terhadap suatu peristiwayang informasinya dipublikasikan sebagai suatu pengumuman. Tujuan Event study (Studi Peristiwa) ini yaitu untuk mengetahui reaksi pasar terhadap peristiwa tertentu, baik peristiwa ekonomis, social, politis, maupun peristiwa lainnya. Studi ini dilakukan ketika seorang peneliti berusaha mencari tahu apakah suatu peristiwa memiliki kandungan informasi atau tidak, apakah peristiwa yang terjadi dapat mengakibatkan pasar bereaksi atau tidak, apakah reaksinya positif atau negatif. Dalam penelitian ini peristiwa yang terjadi adalah peristiwa pengeboman di Indonesia dengan menilai reaksi pasar berdasarkan perubahan harga saham.

Metode penelitian dalam penelitian ini yaitu penelitian yang bersifat empiris yakni penelitian yang melihat secara komprehensif kejadian bencana yang disebabkan oleh peristiwa pengeboman di Indonesia. Adapun jenis data yang digunakan dalam penelitian ini yaitu data sekunder yakni data yang diambil secara tidak langsung, dimana data tersebut berupa informasi dan dokumen. Fokus dalam penelitian ini adalah dampak harga saham yang diakibatkan adanya peristiwa pengeboman di Indonesia pada tahun 2016-2019.

Metode pengumpulan data merupakan suatu cara yang digunakan untuk mendapatkan informasi yang selanjutnya akan dikumpulkan sebagai penelitian. Dalam penelitian ini metode pengumpulan data yang akan digunakan adalah menggunakan teknik dokumentasi. Adapun pengumpulan data dengan metode ini dilakukan dengan cara mengumpulkan beberapa data atau dokumen yang berupa catatan serta informasi yang berkaitan dengan masalah penelitian. Teknik pengumpulan data yang dilakukan pada penelitian ini melalui pencatatan data harga pasar modal saat penutupan (closing) dan indeks harga saham sesuai dengan periode peristiwa. Data yang dipergunakan dalam penelitian ini adalah data sekunder 
yang bersumber dari web resmi pasar modal Indonesia http://www.idx.co.id.

Populasi pada penelitian ini yaitu seluruh harga saham pada perusahaan yang tergabung dalam LQ45 yang benar-benar aktif diperdagangkan di Bursa Efek Indonesia (BEI). Populasi yang digunakan adalah peristiwa teror bom mulai periode tahun 2016 hingga 2019 yaitu sebanyak 4 peristiwa. Bagian dari populasi yang digunakan untuk mewakili dari keseluruhan populasi disebut sampel. Teknik penentuan sampel dalam penelitian ini adalah purposive sampling, yaitu penentuan sampel berdasarkan pada kriteria khusus, yaitu: Peristiwa teror bom dengan jumlah korban terbanyak yang memiliki data closing harian dan data indeks harga saham gabungan harian.

Penelitian ini merupakan studi peristiwa (event study), yaitu penelitian yang mengamati reaksi pasar terhadap suatu peristiwa yang sedang terjadi dengan tujuan untuk mengetahui reaksi harga saham sebelum dan sesudah peristiwa terjadi. Dalam penelitian ini peristiwa yang diamati yaitu peristiwa pengeboman (teror bom). Adapun teknik analisis yang digunakan dalam penelitian ini yaitu dengan melihat atau mengamati data harga saham perusahaan yang tergabung dalam perusahaan LQ45 pada tahun 2016-2019 di web resmi pasar modal Indonesia http://www.idx.co.id setelah mengamati reaksi harga saham pada saat peristiwa pengeboman terjadi di web resmi pasar modal Indonesia, selanjutnya mendeskripsikan dan menganalisis data yang sudah diperoleh.

Periode pengamatan yang dibutuhkan untuk data suatu peristiwa yaitu pre-event, event date dan post-event. Adapun periode pengamatan yang Copyright (C) 2020, FINANCIAL: Jurnal Akuntansi dibutuhkan dalam penelitian ini yaitu selama 7 hari yang terdiri dari 3 hari sebelum peristiwa (pre-event), 1 hari saat peristiwa (event date), dan 3 hari setelah peristiwa (post-event). Karena tanggal 13 Mei 2018 jatuh pada hari Minggu (bukan hari bursa), maka hari Senin, 14 Mei 2018 diasumsikan sebagai event date. Penentuan event date yang mundur dikarenakan tanggal 13 Mei 2018 adalah hari minggu yang merupakan hari libur Bursa Efek Indonesia juga akan memundurkan event date satu hari setelah peristiwa dikarenakan event date yang sesungguhnya terjadi pada hari libur Bursa Efek Indonesia.

\section{HASIL DAN PEMBAHASAN}

Berikut merupakan pemilihan sampel yang ditampilkan dalam tabel sebagai berikut:

\section{Pemilihan Sampel}

\begin{tabular}{|l|lr|c|}
\hline No. & $\begin{array}{l}\text { Kriteria Pemilihan } \\
\text { Sampel }\end{array}$ & Jumlah \\
\hline 1. & $\begin{array}{l}\text { Perusahaan } \\
\text { termasuk pada indeks } \\
\text { saham LQ45 yang } \\
\text { terdaftar di Bursa Efek } \\
\text { Indonesia (BEI) selama } \\
\text { peristiwa pengeboman } \\
\text { berlangsung. }\end{array}$ & 45 \\
\hline 2. & $\begin{array}{l}\text { Perusahaan yang tidak } \\
\text { memiliki ketersediaan } \\
\text { data secara lengkap untuk } \\
\text { keperluan analisis dan } \\
\text { perhitungannya. }\end{array}$ & $(0)$ \\
\hline 3. & $\begin{array}{l}\text { Perusahaan yang } \\
\text { sahamnya tidak aktif di } \\
\text { perdagangkan atau biasa } \\
\text { disebut saham tidur. }\end{array}$ & $(0)$ \\
\hline $\begin{array}{l}\text { Jumlah sampel yang digunakan } \\
\text { dalam penelitian ini. }\end{array}$ & 45 \\
\hline
\end{tabular}

Sumber: Data Sekunder yang di olah, 2020

Berikut adalah indeks harga saham sebelum dan sesudah peristiwa pengobaman di Indonesia pada tahun 
FINANCIAL: Jurnal Akuntansi, Volume 6 Nomor 1, Juni 2020

2016-2019, yang diperoleh dari http://www.idx.co.id.

Tabel 1.1

Indeks Saham Peristiwa Bom Thamrin

\begin{tabular}{|c|c|r|r|}
\hline Tanggal & Indeks & \multicolumn{1}{c|}{ Open } & \multicolumn{1}{c|}{ Close } \\
\hline $11 / 01 / 2016$ & LQ45 & 790.06 & 773.437 \\
\hline $12 / 01 / 2016$ & LQ45 & 773.437 & 786.922 \\
\hline $13 / 01 / 2016$ & LQ45 & 786.922 & 793.301 \\
\hline $14 / 01 / 2016$ & LQ45 & 793.301 & 786.418 \\
\hline $15 / 01 / 2016$ & LQ45 & 786.418 & 784.216 \\
\hline $18 / 01 / 2016$ & LQ45 & 784.216 & 776.22 \\
\hline $19 / 01 / 2016$ & LQ45 & 776.22 & 782.428 \\
\hline
\end{tabular}

Tabel 1.2

Indeks Saham Peristiwa Bom

Kampung Melayu

\begin{tabular}{|c|c|r|r|}
\hline Tanggal & Indeks & \multicolumn{1}{c|}{ Open } & \multicolumn{1}{c|}{ Close } \\
\hline $19 / 05 / 2017$ & LQ45 & 941.45 & 970.396 \\
\hline $22 / 05 / 2017$ & LQ45 & 970.396 & 960.843 \\
\hline $23 / 05 / 2017$ & LQ45 & 960.843 & 959.205 \\
\hline $24 / 05 / 2017$ & LQ45 & 959.205 & 953.238 \\
\hline $26 / 05 / 2017$ & LQ45 & 953.238 & 954.483 \\
\hline $29 / 05 / 2017$ & LQ45 & 954.483 & 953.82 \\
\hline $30 / 05 / 2017$ & LQ45 & 953.82 & 949.509 \\
\hline
\end{tabular}

Tabel 1.3

Indeks Saham Peristiwa Bom Surabaya

\begin{tabular}{|l|l|r|r|}
\hline Tanggal & Indeks & \multicolumn{1}{l|}{ Open } & \multicolumn{1}{c|}{ Close } \\
\hline $08 / 05 / 2018$ & LQ45 & 941.039 & 920.537 \\
\hline $09 / 05 / 2018$ & LQ45 & 920.537 & 954.292 \\
\hline $11 / 05 / 2018$ & LQ45 & 954.292 & 962.01 \\
\hline $14 / 05 / 2018$ & LQ45 & 962.01 & 962 \\
\hline $15 / 05 / 2018$ & LQ45 & 962 & 935.35 \\
\hline $16 / 05 / 2018$ & LQ45 & 935.35 & 935.474 \\
\hline $17 / 05 / 2018$ & LQ45 & 935.474 & 926.907 \\
\hline
\end{tabular}

Tabel 1.4

Indeks Saham Peristiwa Bom Sibolga

\begin{tabular}{|l|l|r|r|}
\hline Tanggal & Indeks & \multicolumn{1}{l|}{ Open } & \multicolumn{1}{c|}{ Close } \\
\hline $06 / 03 / 2019$ & LQ45 & 1007.79 & 1009.31 \\
\hline $08 / 03 / 2019$ & LQ45 & 1009.31 & 994.98 \\
\hline $11 / 03 / 2019$ & LQ45 & 994.98 & 995.416 \\
\hline
\end{tabular}

Copyright (C) 2020, FINANCIAL: Jurnal Akuntansi

\begin{tabular}{|l|l|r|r|}
\hline $12 / 03 / 2019$ & LQ45 & 995.416 & 994.021 \\
\hline $13 / 03 / 2019$ & LQ45 & 994.021 & 996.07 \\
\hline $14 / 03 / 2019$ & LQ45 & 996.07 & 1004.18 \\
\hline $15 / 03 / 2019$ & LQ45 & 1004.18 & 1014.81 \\
\hline $18 / 03 / 2019$ & LQ45 & 1014.81 & 1024.97 \\
\hline
\end{tabular}

\section{Analisis Deskriptif Harga Saham}

Dalam mendiskripsikan data harga saham pre-event, event date dan postevent, dilakukan dengan melihat harga open saham dan harga close saham pada masing-masing emiten yang tergabung dalam indeks LQ45. Jika harga open > close, maka data menunjukkan bahwa terjadi penurunan harga saham, sebaliknya jika harga open < close, maka data menunjukkan bahwa terjadi kenaikan harga saham. Berikut ini adalah kurva hasil penelitian harga saham perusahaan LQ45 pada saat sebelum, sesaat dan sesudah peristiwa terror bom selama periode 20162019.

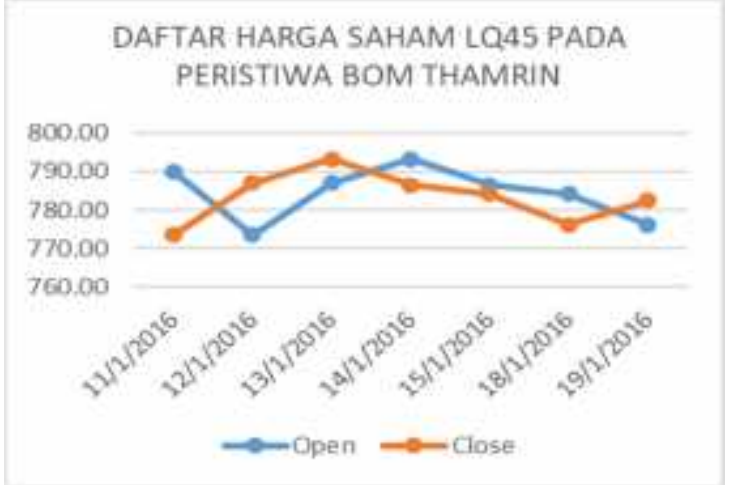

Grafik 2.1

Pada grafik 2.1 menunjukkan bahwa harga saham perusahaan LQ45 pada peristiwa Bom Thamrin yang terjadi pada Januari 2016 mengalami fluktuasi, kenaikan tertinggi terjadi pada $\mathrm{H}-2$ sebelum peristiwa pengeboman terjadi dengan kenaikan senilai 13,485 dari harga sebelumnya. Pada hari $\mathrm{H}$ peristiwa pengeboman, harga saham mengalami penurunan senilai 6,883 dari harga sebelumnya. Pada $\mathrm{H}+1$ peristiwa 
pengeboman, harga saham mengalami penurunan senilai 2,202 dari harga sebelumnya. Sedangkan penurunan yang signifikan terjadi pada $\mathrm{H}-3$ sebelum peristiwa yakni harga saham mengalami penurunan senilai 16,58 dari harga sebelumnya. Dengan demikian, maka dapat diketahui bahwa terdapat perbedaan antara harga saham sebelum dan sesudah teror bom Thamrin. Hal ini terjadi karena pasar merespon dengan cepat peristiwa teror bom Thamrin, dimana pasar merespon negatif peristiwa teror bom Thamrin. Kandungan informasi dalam peristiwa teror bom Thamrin yang terjadi pada tahun 2016 merupakan suatu berita buruk (bad news) bagi pasar modal.

Berdasarkan data pengamatan harga saham yang terdapat pada web resmi pasar modal Indonesia http://www.idx.co.id menunjukkan bahwa harga saham PT H.M. Sampoerna Tbk (HMSP) mengalami penurunan selama 4 hari yakni 2 hari sebelum peristiwa terjadi dan 2 hari setelah peristiwa terjadi. Sedangkan pada saat peristiwa bom Thamrin PT H.M. Sampoerna Tbk (HMSP) justru mengalami kenaikan senilai 600, adapun perusahaan yang mengalami penurunan harga saham yang cukup signifikan pada saat peristiwa bom Thamrin tiga diantaranya yaitu PT Indocement Tunggal Prakarsa Tbk (INTP) dengan penurunan senilai 475 dari harga sebelumnya, PT Unilever Indonesia Tbk (UNVR) dengan penurunan harga senilai 375 dari harga sebelumnya dan PT Matahari Department Store Tbk (LPPF) dengan penurunan senilai 325 dari harga sebelumnya.

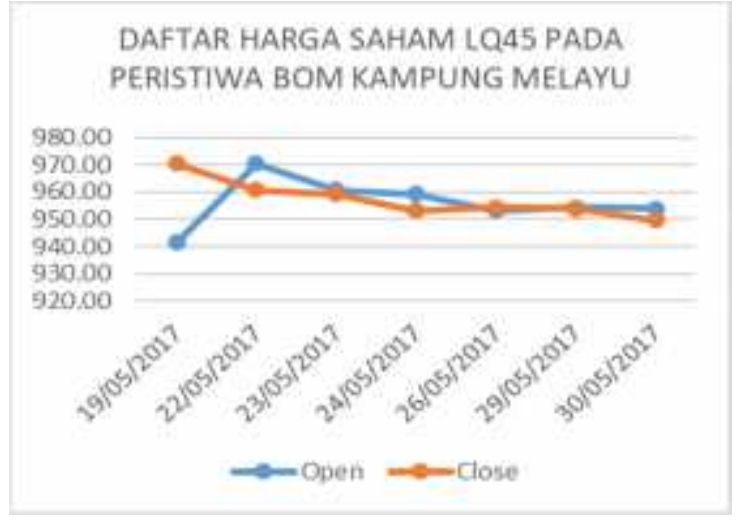

Grafik 2.2

Pada grafik 2.2 menunjukkan bahwa harga saham perusahaan LQ45 pada peristiwa bom Kampung Melayu yang terjadi pada Mei 2017 mengalami fluktuasi, kenaikan tertinggi terjadi pada $\mathrm{H}-3$ sebelum peristiwa pengeboman terjadi dengan kenaikan senilai 28,95. Pada hari $\mathrm{H}$ peristiwa pengeboman, harga saham mengalami penurunan senilai 5,967. Pada $\mathrm{H}+1$ peristiwa pengeboman, harga saham mengalami kenaikan senilai 1,245 dari harga sebelumnya. Sedangkan penurunan yang signifikan terjadi pada $\mathrm{H}-2$ sebelum peristiwa yakni harga saham mengalami penurunan senilai 9,553 dari harga sebelumnya. Dengan demikian, maka dapat diketahui bahwa terdapat perbedaan antara harga saham sebelum dan sesudah teror bom Kampung Melayu. Namun, perbedaan antara harga saham sebelum dan sesudah peristiwa tidak cukup signifikan. Hal ini dapat dilihat dari pergerakan kurva harga saham pada grafik 2.2.

Berdasarkan data pengamatan harga saham yang terdapat pada web resmi pasar modal Indonesia http://www.idx.co.id menunjukkan bahwa harga saham PT Gudang Garam Tbk (GGRM) mengalami penurunan selama 3 hari yakni 2 hari sebelum peristiwa terjadi dan 1 hari setelah peristiwa terjadi. Sedangkan pada saat peristiwa bom Kampung Melayu PT 
Gudang Garam Tbk (GGRM) justru mengalami kenaikan senilai 500 dari harga sebelumnya, adapun perusahaan yang mengalami penurunan harga saham yang cukup signifikan pada saat peristiwa bom Kampung Melayu diantaranya yaitu PT Bank Rakyat Indonesia (Persero) Tbk (BBRI) dengan penurunan senilai 325 dari harga sebelumnya, PT Matahari Department Store Tbk (LPPF) dan PT United Tractors Tbk dengan penurunan harga senilai 500 dari harga sebelumnya dan PT Unilever Indonesia Tbk (UNVR) dengan penurunan senilai 925 dari harga sebelumnya.

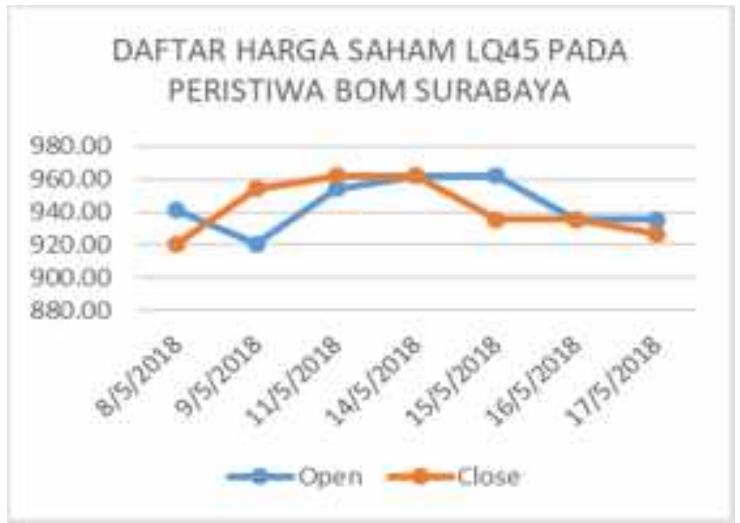

Grafik 2.3

Pada grafik 2.3 menunjukkan bahwa harga saham perusahaan LQ45 pada peristiwa bom Surabaya yang terjadi pada Mei 2018 mengalami fluktuasi, kenaikan tertinggi terjadi pada $\mathrm{H}-2$ sebelum peristiwa pengeboman terjadi dengan kenaikan senilai 33,755 dari harga sebelumnya. Pada hari $\mathrm{H}$ peristiwa pengeboman, harga saham mengalami penurunan senilai 0,01 dari harga sebelumnya. Pada $\mathrm{H}+1$ peristiwa pengeboman, harga saham mengalami penurunan senilai 26,65 dari harga sebelumnya. Dengan demikian, maka dapat diketahui bahwa terdapat perbedaan antara harga saham sebelum dan sesudah teror bom Surabaya. Hal ini terjadi karena pasar merespon dengan cepat peristiwa Copyright (C) 2020, FINANCIAL: Jurnal Akuntansi teror bom Surabaya, dimana pasar merespon negatif peristiwa teror bom Surabaya. Kandungan informasi dalam peristiwa teror bom Thamrin yang terjadi pada tahun 2018 merupakan suatu berita buruk (bad news) bagi pasar modal.

Berdasarkan data pengamatan harga saham yang terdapat pada web resmi pasar modal Indonesia http://www.idx.co.id menunjukkan bahwa harga saham PT Gudang Garam Tbk (GGRM) mengalami penurunan selama 2 hari yakni 1 hari sebelum peristiwa terjadi dan 1 hari saat peristiwa pengeboman terjadi. Adapun perusahaan yang mengalami penurunan harga saham yang cukup signifikan pada saat peristiwa bom Surabaya diantaranya yaitu PT Sawit Sumbermas Sarana Tbk (SSMS) dengan penurunan senilai 125 dari harga sebelumnya, PT Semen Indonesia (Persero) Tbk (SMGR) dengan penurunan harga senilai 200 dari harga sebelumnya dan PT Gudang Garam Tbk (GGRM) dengan penurunan senilai 750 dari harga sebelumnya.

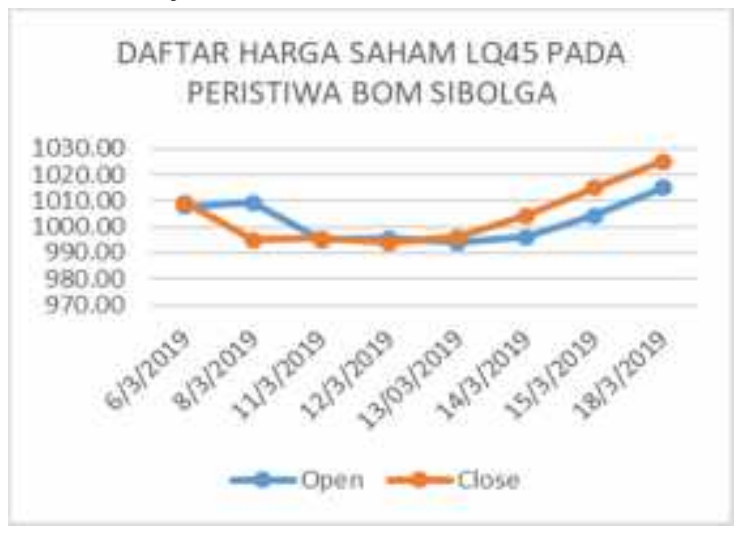

Grafik 2.4

Pada grafik 2.4 menunjukkan bahwa reaksi harga saham pada perusahaan yang tergabung dalam indeks LQ45 dalam peristiwa bom Sibolga yang terjadi pada Maret 2019 tidak mengalami fluktuasi yang signifikan meskipun harga saham pada saat event-date 12 Maret 2019 mengalami penurunan, tetapi pada saat 
event-date 13 Maret 2019 harga saham LQ45 mampu bangkit dengan kenaikan senilai 2,05. Selain itu, pada saat postevent (setelah peristiwa) harga saham LQ45 mengalami kenaikan yang cukup stabil. Hal ini menunjukkan bahwa tidak terdapat pengaruh yang signifikan antara harga saham sebelum dan sesudah peristiwa bom Sibolga yang terjadi pada Maret 2019.

Berdasarkan data pengamatan harga saham yang terdapat pada web resmi pasar modal Indonesia http://www.idx.co.id menunjukkan bahwa dari pengamatan harga saham selama 8 hari yakni 3 hari sebelum peristiwa, 2 hari pada event-date dan 3 hari sesudah peristiwa PT Gudang Garam Tbk (GGRM) yang paling sering mengalami penurunan harga saham yaitu terjadi pada $\mathrm{H}-2$ sebelum peristiwa, Pada hari-H 13 Maret 2019 dan pada $\mathrm{H}+1$ sesudah peristiwa. Adapun perusahaan yang mengalami penurunan harga saham yang cukup signifikan pada saat peristiwa bom Sibolga 12 Maret 2019 diantaranya yaitu PT United Tractors Tbk (UNTR) dengan penurunan senilai 625 dari harga sebelumnya, PT Pabrik Kertas Tjiwi Kimia Tbk (TKIM) dengan penurunan harga senilai 675 dari harga sebelumnya dan PT Indah Kiat Pulp \& Paper Tbk (INKP) dengan penurunan senilai 725 dari harga sebelumnya.

\section{SIMPULAN DAN SARAN}

Berdasarkan hasil penelitian dapat diperoleh kesimpulan bahwa peristiwa pengeboman yang terjadi di Indonesia selama tahun 2016-2019 menimbulkan respon negatif terhadap pasar modal Indonesia terutama pada Perusahaan LQ45. Karena berdasarkan hasil penelitian peristiwa pengeboman yang meliputi Bom
Thamrin, Bom Kampung Melayu, Bom Surabaya, dan Bom Sibolga, pada saat peristiwa harga saham menunjukkan open $>$ close, yang menyebabkan penurunan harga saham. Sehingga rata-rata yang diperoleh dari beberapa peristiwa pengeboman yang terjadi pada tahun 20162019 menunjukkan bahwa terdapat pengaruh yang cukup signifikan terhadap harga saham. Namun dari ke-empat peristiwa pengeboman yang terjadi di Indonesia, perusahaan LQ45 mampu bangkit kembali setelah peristiwa bom sibolga terjadi, sehingga menyebabkan kenaikan harga saham yang cukup signifikan dan menjadikan harga saham perusahaan tersebut kembali stabil.

Semoga artikel ini memberikan manfaat kepada pembaca. Peneliti memberikan saran untuk penelitian selanjutnya diharapkan mampu mengamati kasus yang sama namun dengan tahun yang lebih update (terbaru). Selain itu, untuk penelitian selanjutnya jika mengangkat peristiwa yang sama diharapkan menggunakan variabel dependen yang berbeda seperti return, abnormal return, dan lain-lain. Serta dapat mengamati pada indeks yang berbeda seperti JII, JII 70, ISSI, IDX 30, dan lain.

\section{DAFTAR PUSTAKA}

Arde, M. H. D., \& Kesuma, K. W. (2017). Studi Peristiwa Tragedi Sarinah Terhadap Pasar Modal Indonesia. EJurnal Manajemen Unud, Vol. 6(6), 3080-3110.

Cindy, C., \& Soewarno, N. (2018). Reaksi Harga Saham di Pasar Modal Indonesia Terhadap Peristiwa Teror BOM Periode 2002-2017. Jurnal Akuntansi Universitas Jember, Vol. 15(2), 20-35. https://doi.org/10.19184/jauj.v15i2.68 82 
Jogiyanto, H. (2013). Teori Portofolio dan Analisis Investasi Edisi Kedelapan. BPFE Yogyakarta.

Jusman, J. (2019). Analisis Reaksi Pasar Modal Indonesia Terhadap Peristiwa Peledakan BOM Bunuh Diri di Surabaya (Studi Kasus pada Perusahaan LQ 45 yang Terdaftar di Bursa Efek Indonesia). Jurnal Ilmiah Ekonomi Bisnis, Jilid 5(2), 200-209.

Karmila. (2010). Seluk-Beluk Pasar Modal. KTSP.

Kristiyanto, S., \& Hermuningsih, S. (2018). Pengaruh Peristiwa BOM Thamrin Terhadap Return Saham dan Trading Volume Activity pada Perusahaan LQ45 yang Terdaftar di Bursa Efek Indonesia. Jurnal Manajemen Dewantara, Vol. 2(1), $55-67$.

Manan, A. (2017). Aspek Hukum dalam Penyelenggaraan Investasi di Pasar Modal Syariah Indonesia. In Aspek Hukum dalam Penyelenggaraan Investasi di Pasar Modal Syariah Indonesia. KENCANA.

Mustofa, M. (2002). Memahami Terorisme: Suatu Perspektif Kriminologi. Jurnal Kriminologi Indonesia, Vol. 2(III), 30-38.

Octavera, S., \& Rahadi, F. (2019). Reaksi Pasar Modal terhadap Peristiwa Ekstrim dan Radikalisme ( Studi Pasca Serangan Teroris di Surabaya ). JURNAL MANAJEMEN DAN KEWIRAUSAHAAN, Vol. 10(01), 5969.

Romadhona, J. (2019). Pengaruh Peristiwa BOM Bunuh Diri 13 Mei 2018 di Surabaya Terhadap Abnormal Return dan Volume Perdagangan Perusahaan LQ45 yang Terdaftar di BEI. E-JRA, Vol. 08(03), 1-11.

Sari, N. P. T. P., Purnamawati, G. A., \& Herawati, N. T. (2017). Analisis Komparatif Saham LQ45 Sebelum dan Sesudah Pilpres Amerika Serikat 2016. E-Journal S1 Ak Universitas Pendidikan Ganesha Jurusan
Akuntansi Program S1, Vol. 7(1).

Supramono, G. (2014). Transaksi Bisnis Saham \& penyelesaian Sengketa Melalui Pengadilan. KENCANA.

Tecualu, M., \& Megge, R. (2010). REAKSI PASAR MODAL INDONESIA TERHADAP PERISTIWA BOM KUNINGAN TAHUN 2009. Jurnal Ilmiah Manajemen Bisnis, Vol. 10(1), 19-30.

Utama, C. A., \& Hapsari, L. (2012). Jenis industri, kepemilikan saham asing dan reaksi pasar modal akibat serangan bom teroris. Jurnal Akuntansi Dan Keuangan Indonesia, Vol. 9(2), 100116.

Verawaty, \& Pratiwi, R. (2016). Fluktuasi harga saham perusahaan manufaktur yang terdaftar di bei pasca tragedi ledakan bom sarinah. Jurnal Ilmiah MBiA, Vol. 15(1), 1-10.

Widajatun, V. W., \& Ichsani, S. (2019). Dampak Kejadian Aksi Teroris 20002016 di Indonesia. MANNERS, Vol. II (1)

\section{PROFIL BIODATA}

Maulida Kautsarina, lahir di Kudus 11 Juli 1999, pendidikan terakhir SMA dan lulus pada tahun 2017. Aktivitas yang dijalankan saat ini sebagai aktivis mahasiswa tingkat akhir semester 6 di IAIN Kudus, program sarjana Ekonomi Syariah dan sebagai peneliti pemula.

Izza Alfiatur Rohmaniah, lahir di Kudus 17 September 1999, pendidikan terakhir SMA dan lulus pada tahun 2017. Aktivitas yang dijalankan saat ini sebagai aktivis mahasiswa tingkat akhir semester 6 di IAIN Kudus, program sarjana Ekonomi Syariah dan sebagai peneliti pemula.

Kharis Fadlullah Hana, S.E.Sy, M.E, lahir di Kudus 5 Desember 1991, riwayat pendidikan S1 di STAIN Kudus prodi Syariah dan Ekonomi Syariah lulus pada tahun 2014, dan S2 di STAIN Kudus prodi Syariah dan Ekonomi Syariah lulus pada tahun 2017. Aktivitas sebagai pengajar, peneliti dan aktivis kepemudaan. 